seeming contradictions. Mr. Chubb's paper will doubtless stimulate more thinking and research in the geologic history of the Pacific Islands which is a field in which much work remains to be done before all the eustatic movements can be correlated and island histories deciphered.

P.O. Box 241,

HaRold T. Stearns

WaHIAWA, HaWaII,

16th Jantary, 1962.

\title{
REFERENCES
}

(1) Stearns, H. T., 1961. The Pattern of Some Pacific Island Chains-A Critique. Geol. Mag., Vol. xcvii, p. 170-172.

(2) Stearns, H. T., 1961. Eustatic Shorelines on Pacific Islands. Zeitschrift für Geomorphologie, vol. 3 suppl. pp. 1-16.

(3) Marshall, P., 1927. Geology of Mangaia. Bernice P. Bishop Mus. Bull. 36 , pp. $1-48$.

(4) Stearns, H. T., 1938. Ancient Shorelines on the Island of Lanai, Hawaii : Bull. geol. Soc. Amer., vol. 49, p. 618.

\section{TIE-LINES OF CO-EXISTING PYROXENES}

SiR,-During 1961 several papers and letters have been published in the Geological Magazine, dealing with co-existing pyroxenes in igneous and metamorphic rocks as well as in nodular inclusions in lavas. In order to lessen the apparent controversy, resulting from the different approaches to the probiem by the various authors, it might be useful to compare the results of the thermodynamical calculations of Kretz with the conclusions of the purely chemical approach of Bartholomé.

The formula used for the calculation of the $K_{d}$ value of Kretz is the following :

$$
\begin{aligned}
\mathrm{K}_{\mathrm{d}}-\frac{\mathrm{X}_{0}}{1-\overline{X_{0}}} \cdot \frac{1-\mathrm{X}_{\mathrm{c}}}{\mathrm{X}_{\mathrm{c}}} \text { where } \mathrm{X}_{01} & =\frac{\mathrm{Mg}}{\mathrm{Mg}+\mathrm{Fe}_{2}} \text { in orthopyroxene } \\
\text { and } \mathrm{X}_{\mathrm{c}} & =\frac{\mathrm{Mg}}{\mathrm{Mg}+\mathrm{Fe}_{2}} \text { in clinopyroxene }
\end{aligned}
$$

Consequently the formula for $\mathrm{K}_{\mathrm{d}}$ can be written as follows :

$$
\begin{aligned}
\mathrm{K}_{\mathrm{d}}= & \frac{\left[\frac{\mathrm{Mg}}{\mathrm{Mg}+\mathrm{Fe}_{2}}\right]_{0}}{1-\left[\frac{\mathrm{Mg}}{\mathrm{Mg}+\mathrm{Fe}_{2}}\right]_{0}} \cdot \frac{1-\left[\frac{\mathrm{Mg}}{\mathrm{Mg}+\mathrm{Fe}_{2}}\right]_{\mathrm{c}}}{\left[\frac{\mathrm{Mg}}{\mathrm{Mg}+\mathrm{Fe}_{2}}\right]_{\mathrm{c}}} \\
\mathrm{K}_{\mathrm{d}}= & \frac{\left[\frac{\mathrm{Mg}}{\mathrm{Mg}+\mathrm{Fe}_{2}}\right]_{0}}{\left[\frac{\mathrm{Fe}}{\mathrm{Mg}+\mathrm{Fe}_{2}}\right]_{0}} \cdot \frac{\mathrm{Fe}_{2}}{\left[\frac{\mathrm{Mg}+\overline{\mathrm{Fe}}_{2}}{\mathrm{Mg}}\right]_{\mathrm{c}}} \\
\mathrm{K}_{\mathrm{d}}= & {\left[\frac{\mathrm{Mg}}{\mathrm{Fe}_{2}}\right]_{0} \cdot\left[\frac{\mathrm{Fe}_{2}}{\mathrm{Mg}}\right]_{\mathrm{c}} }
\end{aligned}
$$

The $\mathrm{K}_{\mathrm{t}}$ value of Bartholomé is defined as follows :

$$
\mathrm{K}_{\mathrm{t}}=\left[\frac{\mathrm{Fe}_{2}}{\overline{\mathrm{Mg}}}\right]_{0} \cdot\left[\begin{array}{l}
\mathrm{Mg} \\
\overline{\mathrm{Fe}_{2}}
\end{array}\right]_{\mathrm{c}}
$$

If both formulae are compared it becomes clear that $\mathrm{K}_{\mathrm{t}}=1 / \mathrm{K}_{\mathrm{d}}$. This conclusion is confirmed by the results of the calculations of both authors. 
The average $\mathrm{K}_{\mathrm{t}}$ value for metamorphic co-existing pyroxenes, as calculated by Bartholomé is 1.8 ; the $K_{d}$ value of Kretz for these pyroxenes is 0.54 . These two values are reciprocals. The same holds true for the $K_{t}$ and $K_{d}$ values of magmatic assemblages, which are respectively 1.4 and 0.73 .

As Bartholomé has pointed out, these $\boldsymbol{K}_{t}$ values represent tie-lines in $\mathrm{Ca}-\mathrm{Mg}-\mathrm{Fe}$ diagrams. The $\mathrm{K}_{\mathrm{d}}$ values consequently do the same. The conclusion of Kretz that the construction of tie-lines is a meaningless operation seems therefore not in agreement with his own calculations. Especially in the case of low $K_{t}$ values, which probably correspond with high temperatures, the construction of tie-lines might prove to be useful. In this respect it is interesting to notice that the tie-lines of co-existing pyroxenes from nodular inclusions in lavas all intersect the Wo-Fs side of the triangle, although the average $K_{t}$ value of these pyroxene pairs is $1 \cdot 2$, a value which would lead us to expect an intersection point close to the Wo corner on the Wo-En side of the triangle. The present state of knowledge leads to the conclusion that a shift of the intersection points of the tie-lines to the Wocorner and beyond, points to a high temperature of formation of the coexisting pyroxenes. The only disturbing influence arises from the fact that no common opinion exists on the method of plotting cations other than $\mathrm{Mg}-\mathrm{Ca}-\mathrm{Fe}^{2+}$ in the composition triangle.

\title{
REFERENCES
}

BARTholomé, P., 1961. Co-existing pyroxenes in igneous and metamorphic rocks. Geol. Mag., 98, no. 4.

Brown, G. M., 1961. Co-existing pyroxenes in Igneous Assemblages. Ibid.

KRETZ, R., 1961 (a). Co-existing pyroxenes. Ibid.

- $1961(b)$. Some applications of thermodynamics to co-existing minerals of variable composition : orthopyroxene-clinopyroxene and orthopyroxene-garnet. J. Geol., 69, no. 4.

\section{A. L. G. ColléE.}

\author{
Geologisch en Mineralogisch \\ INSTITUUT DER RIJKSUNIVERSITEIT, \\ GARENMARKT 1B, \\ LEIDEN, \\ Holland. \\ 9th March, 1962.
}

\section{STRUCTURES OF DEVON AND CORNWALL}

SIR,-The letter from Dr. W. R. Dearman published on 1st January, 1962 , in vol. xcviii, part 6 , of this magazine under the heading "Devonian and Carboniferous Stratigraphy" is concerned chiefly with an interpretation of the structure of the tract of country extending from the Cornish coast at Boscastle eastwards to the northern tip of Dartmoor.

Dr. Dearman believes that this tract consists of inverted strata with a low northerly regional dip. He says that the inverted strata belong to the upper limb of a syncline and that a complementary anticline must lie to the north. I show his reconstruction in Text-fig. $1 a$.

But this is not the only reconstruction that can be made. In Text-fig. $1 b$ I show another. Here the inverted strata are the lower limb of an anticline facing downward and to the north.

The direct evidence available at the moment does not allow us to decide which, if either, of these reconstructions is correct. But the fundamental difference between them is that Dr. Dearman's involves, as he says, " a general southerly sense of translation" (i.e. overriding southerly rock transport), while the alternative reconstruction involves northerly transport. 